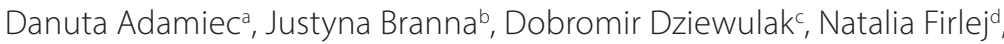
Kamila Groszkowskae, Marta Karkowskaf, Daniela Kupis's, Marcin Mróz' Jarosław Szymanek', Angelina Tazuszeli, Łukasz Żołądek ${ }^{k}$

\title{
Uregulowania dotyczące wniosków formalnych zawarte w regulaminach parlamentów wybranych państw członkowskich UE, Wielkiej Brytanii, Stanów Zjednoczonych i Parlamentu Europejskiego $^{1}$
}

\author{
Regulations concerning 'points of order' stipulated in the rules \\ of procedure in selected EU Member States, the United Kingdom, \\ the United States and the European Parliament
}

\begin{abstract}
The paper concerns selected issues related to parliamentary procedures. The primary aim is to investigate a particular category of motions, defined by rules of procedure of the Polish parliament as points of order (literally "formal motions"). In Poland, points of order are recognised as a separate category of motions. They may be submitted only in respect of matters being the subject of the orders of the day or the proceedings in a sitting and include, inter alia, motions to: suspend, postpone or close the sitting; close the discussion; alter the procedure of the discussion; close the list of speakers; limit the time of speeches; confirm a quorum. The authors examine how motions of similar subject scope are regulated in foreign national parliaments.
\end{abstract}

Keywords: point of order, standing orders of parliament, parliament

W opracowaniu omówiono przepisy regulaminów parlamentów narodowych wybranych państw członkowskich UE, a także Wielkiej Brytanii, Stanów Zjednoczonych i regulaminu Parlamentu Europejskiego, odnoszące się do kwestii objętych w regulaminie Sejmu RP pojęciem „wniosków formalnych". Pojęcie to nie zostało wyodrębnione we wszystkich omówionych regulaminach parlamentarnych. W wielu z nich regulacja odpowiadająca przedmiotowo poszczególnym wnioskom formalnym wyodrębnionym na gruncie regulaminu Sejmu pozostaje rozproszona. Z kolei w niektórych regulaminach, choć pojęcie wniosku formalnego zostało wyodrębnione, to nie zostało ono zdefiniowane i nie przewidziano zamkniętego katalogu takich wniosków.

Słowa kluczowe: wniosek formalny, regulamin parlamentu, parlament

Doktor nauk prawnych, specjalista ds. informacji europejskiej •

Kancelaria Sejmu, Biuro Analiz Sejmowych, Wydział Analiz Prawa Międzynarodowego

i Zagranicznych Systemów Prawnych, WARSZAWA, POLSKA •

danuta.adamiec@sejm.gov.pl • https://orcid.org/0000-0002-6600-4309

1 Informacja na temat uregulowań dotyczacych wniosków formalnych zawartych $w$ regulaminach parlamentów wybranych państw członkowskich UE, Wielkiej Brytanii, Stanach Zjednoczonych i Parlamentu Europejskiego sporządzona 9 grudnia 2020 r. na zlecenie Dyrektora Biura Analiz Sejmowych, BAS-ZSP-2671/20. 
b Specjalista ds. informacji europejskiej -

Kancelaria Sejmu, Biuro Analiz Sejmowych, Wydział Analiz Prawa Międzynarodowego i Zagranicznych Systemów Prawnych, WARSZAWA, POLSKA •

justyna.branna@sejm.gov.pl • https://orcid.org/0000-0002-9653-9996

c Doktor nauk humanistycznych, adiunkt

Uniwersytet Warszawski, Wydział Pedagogiczny, Katedra Dydaktyki i Pedeutologii, WARSZAWA, POLSKA

dobromir.dziewulak@uw.edu.pl • https://orcid.org/0000-0002-7974-8024

d Specjalista ds. informacji europejskiej •

Kancelaria Sejmu, Biuro Analiz Sejmowych, Wydział Analiz Prawa Międzynarodowego i Zagranicznych Systemów Prawnych, WARSZAWA, POLSKA •

natalia.firlej@sejm.gov.pl • https://orcid.org/0000-0002-9522-5522

e Specjalista ds. międzynarodowych

Kancelaria Sejmu, Biuro Analiz Sejmowych, Wydział Analiz Prawa Międzynarodowego ¡ Zagranicznych Systemów Prawnych, WARSZAWA, POLSKA .

kamila.groszkowska@sejm.gov.pl • https://orcid.org/0000-0002-8618-1302

f Doktor nauk humanistycznych, adiunkt -

Polska Akademia Nauk, Instytut Filozofii i Socjologii, WARSZAWA, POLSKA •

mkarkowska@ifispan.edu.pl • https://orcid.org/0000-0003-0747-4332

g Specjalista ds. informacji europejskiej •

Kancelaria Sejmu, Biuro Analiz Sejmowych, Wydział Analiz Prawa Międzynarodowego

i Zagranicznych Systemów Prawnych, WARSZAWA, POLSKA •

daniela.kupis@sejm.gov.pl . https://orcid.org/0000-0003-0075-9837

h Specjalista ds. międzynarodowych

Kancelaria Sejmu, Biuro Analiz Sejmowych, Wydział Analiz Prawa Międzynarodowego

i Zagranicznych Systemów Prawnych, WARSZAWA, POLSKA •

marcin.antoni.mroz@gmail.com • https://orcid.org/0000-0001-5033-2132

Doktor hab. nauk humanistycznych, specjalista ds. społecznych •

Kancelaria Sejmu, Biuro Analiz Sejmowych, Wydział Analiz Społecznych i Ekonomicznych, WARSZAWA, POLSKA -

jaroslaw.szymanek@sejm.gov.pl • https://orcid.org/0000-0002-0590-5218

Specjalista ds. informacji europejskiej

Kancelaria Sejmu, Biuro Analiz Sejmowych, Wydział Analiz Prawa Międzynarodowego

i Zagranicznych Systemów Prawnych, WARSZAWA, POLSKA •

angelina.tazuszel@sejm.gov.pl • https://orcid.org/0000-0003-2436-256X

k Specjalista ds. międzynarodowych •

Kancelaria Sejmu, Biuro Analiz Sejmowych, Wydział Analiz Prawa Międzynarodowego

i Zagranicznych Systemów Prawnych, WARSZAWA, POLSKA •

lukasz.zoladek@sejm.gov.pl • https://orcid.org/0000-0001-5247-6228 


\section{Przedmiot opracowania}

W opracowaniu przedstawiono informacje na temat uregulowań dotyczących wniosków formalnych zawartych w regulaminach 19 parlamentów wybranych państw: państw członkowskich UE (Austrii, Belgii, Czech, Danii, Estonii, Finlandii, Francji, Hiszpanii, Irlandii, Luksemburga, Łotwy, Niderlandów, Niemiec, Portugalii, Słowacji, Szwecji, Włoch), a także Stanów Zjednoczonych, Wielkiej Brytanii oraz Parlamentu Europejskiego (dalej: PE). W przygotowaniu niniejszej informacji wykorzystano obcojęzyczne akty prawne oraz obcojęzyczną i polską literaturę przedmiotu. Przeanalizowano regulaminy izb oraz informacje dostępne na stronach internetowych poszczególnych parlamentów. Posiłkowano się także materiałami znajdującymi się w bazie Europejskiego Centrum Badań i Dokumentacji Parlamentarnej (European Centre for Parliamentary Research and Documentation, ECPRD).

\section{Wnioski z opracowania}

Kategoria wniosków formalnych, niezależnie od tego jak nazwanych, jest obecna w większości przepisów regulaminowych parlamentów świata. Nie zawsze jednak wnioski takie nazywane są wprost wnioskami formalnymi czy - co występuje bodajże najczęściej - wnioskami proceduralnymi bądź porządkowymi, a częstą praktyką jest ich określenie przedmiotowe (np. wniosek o zamknięcie obrad, wniosek o odesłanie do komisji, wniosek o przestrzeganie regulaminu, wniosek o zmianę sposobu głosowania).

Konfrontując uwagi porównawcze z przepisami art. 184 regulaminu Sejmu, należy jednak zwrócić uwagę, że, po pierwsze, bardzo rzadko wnioski o charakterze formalnym są przedmiotem uregulowania w jednym obszernym artykule (wyjątkiem jest PE oraz - w mniejszym stopniu - Słowacja i Włochy). Najczęściej są one rozproszone w całym tekście regulaminu. Po drugie, w wielu wypadkach są one istotnie limitowane i sprowadzone do kluczowych spraw, stąd też polskie rozwiązanie przewidujące aż 12 typów wniosków formalnych (czy też zakresów, jakich mogą one dotyczyć) jest ewenementem. Zazwyczaj w regulaminach parlamentarnych przewidzianych jest kilka (ok. pięciu) spraw, które odpowiadają polskiemu wnioskowi formalnemu. Są to najczęściej wnioski o:

- zmianę porządku obrad,

- zmianę sposobu głosowania lub odroczenie głosowania,

- zamknięcie debaty,

- odesłanie do komisji,

- przestrzeganie regulaminu.

Po trzecie, bardzo często występują rozmaitego rodzaju ograniczenia związane z dopuszczalnością wniosku formalnego. Ograniczenia takie zazwyczaj sprowadzają się do: 
- wskazania minimalnej liczby posłów, którzy z wnioskiem mogą wystąpić (np. w Luksemburgu co najmniej 5 posłów),

- ograniczenia możliwości wystąpienia z jednym rodzajem wniosku formalnego w trakcie trwania jednego posiedzenia (np. Słowacja),

- wyraźnego zastrzeżenia, że nie jest możliwe zgłoszenie wniosku w sprawie podobnej czy identycznej, jeśli wniosek został już wcześniej odrzucony (np. Niemcy),

- ograniczenia czasu na przedstawienie wniosku formalnego (od minuty do kilku minut, np. w Parlamencie Europejskim maksymalnie jedna minuta, w niemieckim Bundestagu 5 minut),

- ograniczenia ewentualnej dyskusji nad wnioskiem (we Włoszech maksymalnie do 5 minut),

- całkowitego wyłączenia dyskusji nad wnioskiem (Słowacja),

- możliwości odebrania głosu przez przewodniczącego w sytuacji, kiedy mówca odbiega od meritum (PE),

- ograniczenia czasowego związanego z przedkładaniem niektórych wniosków (np. wnioski o zmianę porządku posiedzenia muszą być złożone przed jego rozpoczęciem - Austria, Włochy),

- nakazu pisemnego sformułowania wniosku (np. Czechy, Słowacja, Łotwa),

- konieczności wskazania przepisu regulaminowego, który został naruszony w razie wniosku o złamanie regulaminu (Stany Zjednoczone, PE),

- przyznania przewodniczącemu izby pewnej uznaniowości w dopuszczaniu posłów do zgłaszania wniosków (Belgia, Dania, Hiszpania, USA, Luksemburg),

- przyznania przewodniczącemu izby fakultatywności w poddawaniu wniosków pod głosowanie, co jest skorelowane z założeniem, że dysponentem wniosku jest przewodniczący a nie izba (Włochy),

- prawa każdego członka izby do wystąpienia z żądaniem przedstawienia wniosku w formie pisemnej (USA),

- niepoddawania wniosków pod głosowanie w razie przekonania, że większość członków izby popiera go, czyli domniemanie jego przyjęcia (Słowacja),

- preferencyjnego traktowania wniosków formalnych zgłoszonych np. przez rząd (Francja).

Należy ponadto zauważyć, że poszczególne rozwiązania dotyczące wniosków formalnych najczęściej nie są samoistne. Wiążą się one m.in.: a) z ogólną koncepcją roli przewodniczącego izby (podmiot niezależny albo osoba wspierająca większość parlamentarną); b) dopuszczeniem innych niż sam regulamin sposobów uregulowania pracy izby i, co za tym idzie, odwoływanie się do praktyki, zwyczajów i obyczajów parlamentarnych; c) mechanizmami organizacji dyscypliny partyjnej w obrębie klubów parlamentarnych. 


\section{Pojęcie wniosku formalnego}

Treścią regulacji zawartej w art. 184 regulaminu Sejmu jest instytucja tzw. wniosku formalnego. Wniosek formalny jest szczególnego rodzaju wnioskiem. Podstawą formalną wniosku materialnego jest art. 14 ust. 1 pkt 1 ustawy o wykonywaniu mandatu posła i senatora, który stanowi, że w wykonywaniu swoich obowiązków poselskich poseł w szczególności ma prawo „zgłaszać wnioski w sprawach rozpatrywanych na posiedzeniach Sejmu i Senatu i jego organów”. Oznacza to, że „wnioski materialne, tam gdzie ich stawianie przez posłów (indywidualnie lub grupowo) jest dopuszczalne, służą wprost realizacji kompetencji Sejmu"'.

$\mathrm{W}$ przeciwieństwie do wniosków materialnych wnioski formalne są w istocie wnioskami, których celem nie jest oddziaływanie na treść rozstrzygnięć podejmowanych przez izbę, tylko skorygowanie toku pracy izby. Istotą każdego wniosku formalnego jest to, że jego przyjęcie „oznacza ingerencję i z reguły skorygowanie toku obrad nad poszczególnymi punktami porządku dziennego, odejście od toku wzorcowego, który polega na swobodzie kierowania obradami przez Marszałka Sejmu” ${ }^{3}$. Ponadto należy mieć na uwadze, że wnioski formalne „mogą dotyczyć wyłącznie spraw będących przedmiotem porządku dziennego i przebiegu posiedzenia" (art. 184 ust. 2 regulaminu). Oznacza to, że rozstrzygnięcie podjęte na podstawie zgłoszonego wniosku formalnego odnosi się wyłącznie do konkretnej sprawy porządku dziennego.

$\mathrm{W}$ efekcie wniosek formalny to wniosek składany w toku plenarnego posiedzenia Sejmu, poza porządkiem obrad, wyłącznie w sprawach będących przedmiotem porządku dziennego i przebiegu posiedzenia, którego zakres przedmiotowy jest enumeratywnie zapisany w treści art. 184 regulaminu Sejmu ${ }^{4}$.

W art. 184 regulaminu Sejmu wskazano, że do wniosków formalnych zalicza się wnioski o 12 różnych czynności, m.in. wniosek o przerwanie, odroczenie lub zamknięcie posiedzenia; wniosek o uchwalenie tajności posiedzenia; wniosek o stwierdzenie kworum; wniosek o odesłanie do komisji; wniosek o zmianę w sposobie prowadzenia dyskusji; wniosek o przeliczenie głosów. Artykuł 184 regulaminu Sejmu określa tryb postępowania w odniesieniu do wniosków formalnych, m.in. zgłoszenie ustne $\mathrm{w}$ trakcie obrad (co do zasady), rozstrzyganie większością głosów, wystąpienie trwające nie dłużej niż 2 minuty.

W regulaminach parlamentów wybranych państw członkowskich UE oraz Parlamentu Europejskiego, które przedstawiono w niniejszym opracowaniu,

2 P. Sarnecki, Art. 184 [w:] Komentarz do Regulaminu Sejmu Rzeczypospolitej Polskiej, red. A. Szmyt, Warszawa 2018, s. 832.

3 Ibidem, s. 184.

4 Por. P. Chybalski, Wniosek formalny [w:] Wielki słownik parlamentarny, red. J. Szymanek, Warszawa 2018, s. 1081. 
wnioski formalne, tak lub podobnie nazwane, stanowią odrębną kategorię w Belgii, Estonii, Francji, Luksemburgu, Niderlandach, Niemczech, we Włoszech i na Słowacji. Poza tym kategoria wniosku formalnego, pod nazwą wniosku proceduralnego, występuje też na gruncie regulaminu Parlamentu Europejskiego. Natomiast niektóre czynności wymienione w art. 184 regulaminu Sejmu, które odpowiadają kwestiom tradycyjnie podejmowanym we wnioskach formalnych, w regulaminach parlamentów Austrii, Czech, Danii, Finlandii, Hiszpanii, Irlandii, Łotwy i Szwecji są przedmiotem wniosków proceduralnych lub porządkowych. W tym ostatnim przypadku nie są one jednak skategoryzowane i objęte jednym wspólnym mianem ani jednakowym trybem postępowania. Często z uwagi na specyfikę określonych czynności do każdej z nich stosuje się pewne odmienności proceduralne. Ponadto są one ujęte w różnych przepisach regulaminów parlamentów i nie składają się na jedną kategorię podlegającą temu samemu trybowi postępowania.

\section{Przegląd porównawczy}

\section{AUSTRIA - Rada Narodowa (Nationalrat)}

W parlamencie Austrii odpowiednikiem regulaminu Sejmu jest akt prawny o nazwie „Ustawa o porządku obrad Rady Narodowej” - Bundesgesetz über die Geschäftsordnung des Nationalrates (w skrócie ustawa o porządku obrad - Geschäftsordnungsgesetz 1975, GOG-NR) ${ }^{5}$. Ustawa ta nie zawiera terminu czy kategorii „wniosek formalny”. Nie znalazł tu także zastosowania tzw. wniosek porządkowy (Geschäftsordnungsantrag) ${ }^{6}$, z jakim mamy do czynienia np. w niemieckim Bundestagu ${ }^{7}$.

$\mathrm{W}$ regulaminie poświęcono odrębne miejsce jedynie wybranym kwestiom dotyczącym zmian $\mathrm{w}$ porządku dziennym posiedzenia lub sprawom mającym wpływ na przebieg posiedzeń. Zawarto je głównie w $\$ 49$ i $\$ 50$, zaś kluczowym kwestiom poświęcono fragment $\$ 49$ ust. 5 ustawy o porządku obrad, który dotyczy zmian w porządku obrad (Tagesordnung).

Zgodnie z tym przepisem Rada Narodowa może zdecydować większością 2/3 głosów o tym, że punkt porządku obrad zostanie z niego usunięty lub że punkt nieuwzględniony w porządku obrad zostanie poddany debacie. Taka decyzja podejmowana jest na wniosek przewodniczącego izby lub na wniosek posła na samym początku posiedzenia, wyłącznie przed ogłoszeniem przejścia do porządku obrad (Vor Eingang in die Tagesordnung). Zaznaczyć należy, że zgodnie z $\$ 49$ ust. 4 ustawy o porządku obrad przed przejściem do porządku obrad przewod-

5 Https://www.ris.bka.gv.at/GeltendeFassung.wxe?Abfrage=Bundesnormen\&Gesetzes nummer $=10000576$.

6 Https://www.ris.bka.gv.at.

7 Zob. informacja dotycząca wniosku formalnego w Niemczech. 
niczący może zmienić kolejność lub połączyć kilka punktów porządku obrad, by przeprowadzić nad nimi jedną debatę. W razie sprzeciwu co do takich zmian przedstawionego przez posłów, Rada Narodowa podejmuje decyzję bez debaty w zwykłym trybie (większością głosów).

W $₫ 49$ ust. 6 wskazano też, że przewodniczący, po konsultacji z członkami Konferencji Prezydialnej Rady Narodowej (Präsidialkonferenz dem Nationalrat) ${ }^{8}$, którą tworzą przewodniczący Rady Narodowej oraz przedstawiciele klubów parlamentarnych, może zaproponować Radzie Narodowej usunięcie jednego lub więcej punktów z porządku obrad już w trakcie posiedzenia, po przejściu do porządku obrad. Ostatecznie przedstawienie takiej propozycji leży wyłącznie w gestii przewodniczącego izby i jest jego samodzielną decyzją. Po ogłoszeniu takiej propozycji finalną decyzję $\mathrm{w}$ sprawie usunięcia jednego lub więcej punktów z porządku obrad bez debaty podejmuje Rada Narodowa większością dwóch trzecich głosów.

Do kwestii związanych z porządkiem dziennym obrad już po jego ustaleniu, ale przed otwarciem porządku dziennego obrad, nawiązano także w kolejnym paragrafie, gdzie mowa o sprzeciwie do porządku dziennego ogłoszonego przez przewodniczącego izby.

Zgodnie z $\$ 50$ istnieje możliwość zgłoszenia przez posłów sprzeciwu do ogłoszonego wcześniej porządku obrad. Wynika to z regulaminu, w którym mowa o tym, że przewodniczący co do zasady ogłasza dzień, godzinę i - jeśli to możliwe - porządek obrad następnej zaplanowanej sesji na koniec każdego takiego spotkania Rady. Zgodnie z $\$ 50$ ust. 1 może to również zrobić za pomocą pisemnego zawiadomienia rozesłanego $\mathrm{w}$ sali plenarnej.

W razie wniesienia takiego sprzeciwu dotyczącego porządku obrad i w sytuacji, gdy przewodniczący nie przyłączy się do niego, to Rada Narodowa decyduje o przyjęciu lub odrzuceniu sprzeciwu (w zwykłym trybie). Decyzję poprzedza ogólna debata nad wszystkimi zgłoszonymi w takim wypadku sprzeciwami. Jest ona obligatoryjna. Parlamentarzyści mogą zgłosić sprzeciw wobec jednego punktu, ale też kilku. Przewodniczący może ograniczyć czas wypowiedzi poszczególnych posłów do 5 minut, a liczbę mówców do trzech na klub. Na wniosek pięciu posłów należących do tego samego klubu odbywa się odrębna debata dotycząca wszystkich zastrzeżeń zgłoszonych przez ten klub, przy czym przewodniczący może ograniczyć czas wystąpień i liczbę mówców w taki sam sposób jak w ogólnej debacie. W przypadku większej liczby zastrzeżeń przewodniczący ustala kolejność debat nad kolejnymi sprzeciwami, biorąc pod uwagę ogólne za-

8 Konferencja Prezydialna Rady Narodowej jest organem doradczym przy opracowywaniu planów pracy Rady Narodowej, ustalaniu porządków obrad i terminów posiedzeń oraz koordynowaniu prac komisji. Jego rola jako organu arbitrażowego ma kluczowe znaczenie dla prac parlamentarnych: zwłaszcza w przypadku konfliktów dotyczących interpretacji i stosowania regulaminu. 
sady, o których mowa w $\$ 60$ ust. $3^{9}$. Wszystkie zgłoszone zastrzeżenia muszą być poddane pod głosowanie po odbyciu debaty lub w przypadku debat wielokrotnych - po ostatniej z nich. Wobec braku sprzeciwu większości posłów co do sposobu prowadzenia obrad (np. kolejności poruszanych spraw w przypadku debat wielokrotnych) przyjmuje się propozycję przewodniczącego w tej sprawie.

\section{BELGIA - Izba Reprezentantów (Ia Chambre)}

Regulacje dotyczące wniosków formalnych (un rappel au Règlement) w regulaminie Izby Reprezentantów (Règlement de la Chambre ${ }^{10}$ ) zostały określone w art. 44 ust. 7 oraz art. 49 ust. 2.

Zgodnie z ogólną zasadą wyrażoną w art. 44 ust. 1 regulaminu deputowany nie może zabierać głosu podczas posiedzenia, o ile nie zostanie zarejestrowany lub o ile przewodniczący izby nie udzieli mu głosu na jego prośbę. Artykuł 44 ust. 7 regulaminu określa, że przewodniczący izby może ${ }^{11}$ zezwolić deputowanemu na przerwanie osobie, której przyznano prawo głosu, tylko z powodu zgłoszenia wniosku formalnego, jest to jednak zawsze swobodna decyzja przewodniczącego. Może on udzielić także zgody na krótką interwencję, o ile dotyczy ona omawianego właśnie tematu. Jeżeli taki deputowany odbiega od tematu, przewodniczący pozbawia go prawa głosu. Deputowany, który został pozbawiony głosu, nie może złożyć kolejnego wniosku formalnego lub przerwać wypowiedzi innej osoby po raz drugi w czasie tego samego posiedzenia. Jeżeli deputowany nie przerywa swojej wypowiedzi, mimo pozbawienia go prawa głosu przez przewodniczącego izby, przewodniczący może zadecydować o nieuwzględnianiu wypowiedzi deputowanego w protokole posiedzenia.

Zgodnie z art. 49 ust. 2 regulaminu deputowany może zawsze zwrócić się do przewodniczącego o udzielenie prawa głosu w celu zgłoszenia wniosku formalnego, w celu zajęcia stanowiska w debacie na temat porządku obrad, ustalania treści pytań lub przyznania priorytetu określonemu punktowi obrad. Artykuł 49 nie określa, ile wniosków formalnych można wnieść, nie precyzuje również, ile czasu deputowany ma na zabranie głosu.

9 Przewodniczący ustala kolejność, w jakiej wypowiadają się posłowie, o ile rozstrzygająca nie jest kolejność zgłoszeń. Jeżeli dwóch lub więcej mówców „za” lub dwóch lub więcej mówców „przeciw” zarejestruje się w tym samym czasie, przewodniczący ustala kolejność tak, by jako pierwszy głos zabrał mówca „przeciw”, a następnie, na przemian mówili posłowie „za” i „przeciw”. Przewodniczący jest też zobowiązany prowadzić debatę w taki sposób, aby w jej trakcie mogły być zaprezentowane wszystkie punkty widzenia dotyczące danej kwestii. Jest też zobowiązany wziąć pod uwagę siłę klubu i różnorodność mówców z każdego z nich.

10 Règlement de la Chambre, https://www.dekamer.be/kvvcr/pdf_sections/publications/reglement/reglementFR.pdf.

11 „Le président peut autoriser un membre à interrompre un orateur uniquement pour un rappel au Règlement ou pour une courte intervention sur le fond de la question”. 


\section{CZECHY - Izba Poselska (Poslanecká sněmovna)}

W regulaminie czeskiej Izby Poselskiej ${ }^{12}$ kwestię składania wniosków przez posłów uregulowano $\mathrm{w} \$ 63. Przepis ten przewiduje różne rodzaje wniosków ${ }^{13}$, a ich przedmiot w niektórych wypadkach może stanowić odpowiednik spraw, które obejmuje wniosek formalny określony w art. 184 regulaminu Sejmu (np. wniosek o odesłanie do innego organu Izby Poselskiej).

Zgodnie z $\$ 63$ ust. 1 poseł może podczas debaty przedstawiać wnioski - mają one odnosić się do konkretnej omawianej sprawy i musi z nich wynikać, jaką Izba ma podjąć decyzję. Przewodniczący może poprosić posła o doprecyzowanie wniosku lub przedłożenie go na piśmie. Zgodnie z $\$ 65$ wnioskujący przedstawia wniosek w swoim języku ojczystym. Jeżeli wnioskujący nie mówi po czesku, jego wystąpienie jest tłumaczone na język czeski, o ile zwróci się o to przynajmniej jeden poseł.

Ponadto w regulaminie Izby Poselskiej w $\$ 60$ przewidziano możliwość wygłoszenia przez posła tzw. uwagi faktycznej (faktická poznámka), w której reaguje on na przebieg debaty. Za uwagę faktyczną uznaje się również wniosek proceduralny (procedurální návrh) odnoszący się do sposobu rozpatrzenia danego punktu porządku obrad. W ramach uwagi faktycznej nie można przedstawiać merytorycznego stanowiska w omawianej sprawie. Poseł, który zgłasza się do uwagi faktycznej, otrzymuje głos w pierwszej kolejności, jednak bez przerywania osobie, która właśnie zabiera głos ${ }^{14}$. Z brzmienia $\$ 60$ ust. 1 wynika, że przewodniczący udziela głosu posłowi, który zgłasza się do wygłoszenia uwagi faktycz-

12 Jednací řád Poslanecké sněmovny, https://www.psp.cz/docs/laws/1995/90_index.html.

13 Wyróżnia się następujące rodzaje wniosków (návrhy):

1) wniosek o odroczenie (poseł proponuje rozpatrzenie omawianego projektu w późniejszym terminie),

2) wniosek o odrzucenie (w wyniku przyjęcia takiego wniosku projekt nie będzie już przedmiotem debaty ani głosowania),

3) wniosek o odesłanie do innego organu Izby Poselskiej (ze wskazaniem terminu na zakończenie przez ten organ prac),

4) wniosek w sprawie rozpatrzenia innego projektu (gdy w tej samej sprawie przedłożono więcej niż jeden projekt, izba decyduje, który rozpatrzyć),

5) wniosek zmieniający (zmiana, pominięcie lub uzupełnienie pierwotnego tekstu, przy czym do wniosku zmieniającego nie można złożyć kolejnego wniosku zmieniającego),

6) wniosek ewentualny (gdy rozstrzygnięcie danej sprawy wymaga rozstrzygnięcia innej sprawy),

7) wniosek dodatkowy (rozszerzenie lub uzupełnienie pierwotnego tekstu, jeżeli nie można złożyć wniosku zmieniającego),

8) wniosek warunkowy (uzależnia ważność uchwały od spełnienia określonego warunku, przy czym wniosek warunkowy nie może być przyjęty przy uchwalaniu projektu ustawy),

9) wniosek o usunięcie części projektu (sekcji, paragrafu, akapitu itp.).

14 „Poslanec, který se přihlásil k faktické poznámce, dostane slovo přednostně”. 
nej. W regulaminie nie wprowadzono ograniczenia ilościowego $\mathrm{w}$ odniesieniu do zgłaszania uwag faktycznych. Zgodnie z $\$ 60$ ust. 2 czas na przedstawienie uwagi faktycznej nie może przekroczyć 2 minut (tyle samo czasu przewidziano na ewentualną odpowiedź na uwagę faktyczną). Jeżeli wypowiedź posła nie jest uwagą faktyczną lub gdy poseł przekroczy czas przewidziany na wygłoszenie uwagi faktycznej, przewodniczący może odebrać głos posłowi. Decyzja przewodniczącego w tej sprawie ma charakter ostateczny ( $\$ 60$ ust. 3).

\section{DANIA - Folketing}

W regulaminie Folketingu ${ }^{15}$ nie ma odrębnego artykułu opisującego wnioski formalne, niemniej regulamin pozwala, choć w ograniczonej formie, wystąpić z wnioskiem poza kolejnością mówców, w wybranych sprawach proceduralnych, wskazanych wprost w poszczególnych przepisach regulaminowych.

Zgodnie $\mathrm{z}$ art. 28 regulaminu Folketingu przewodniczący udziela głosu deputowanym w kolejności, w jakiej zostali oni zgłoszeni, przy czym pierwszeństwo ma m.in. sprawozdawca. Przewodniczący może zmienić kolejność udzielania głosu, m.in. z powodów praktycznych. Niezależnie od ustalonego porządku i czasu wystąpień przewodniczący może, na ile jest to uzasadnione, udzielić głosu deputowanemu w celu wygłoszenia krótkich uwag, przy czym wprowadzono ograniczenie liczby i czasu takich wystąpień. Deputowany może wygłosić dwie krótkie uwagi - pierwszą 1-minutową, drugą 30-sekundową. W szczególnych okolicznościach przewodniczący może udzielić głosu w celu wygłoszenia krótkiej uwagi więcej razy lub na dłuższy czas.

Ponadto w regulaminie Folketingu w poszczególnych artykułach zostały uregulowane wybrane zagadnienia związane $\mathrm{z}$ kwestiami formalnymi, jak np.: a) w art. 31 regulaminu Folketingu przewidziano, że 17 deputowanych może zwrócić się na piśmie o zamknięcie punktu porządku dziennego bez debaty; b) w art. 35 przewidziano, że 17 deputowanych może złożyć wniosek o przeprowadzenie głosowania imiennego.

\section{ESTONIA - Riigikogu}

$\mathrm{W}$ regulaminie estońskiego parlamentu (Riigikogu) ${ }^{16}$ nie zawarto postanowień dotyczących treści wniosków formalnych. Regulacje zapisane w $\$ 74$ regulaminu dotyczą przede wszystkim sposobu zgłaszania zastrzeżeń oraz pytań związanych $\mathrm{z}$ porządkiem obrad (protests and questions concerning points of order), które od-

15 Standing Orders of the Danish Parliament, 2018, https://www.ft.dk/ /media/sites/ $\mathrm{ft} /$ pdf/publikationer/engelske-publikationer-pdf/forretningsorden_engelsk_2018_ samlet_web.ashx.

16 Riigikogu Rules of Procedure and Internal Rules Act (angielskie tłumaczenie aktu prawnego zamieszone na stronie internetowej Riigikogu), RT I 2007, 44, 316, https:// www.riigiteataja.ee/en/eli/521032019014/consolide. 
noszą się do stwierdzenia przez posła naruszenia przepisów regulujących przebieg posiedzenia.

Zgodnie z postanowieniami $\$ 74$ regulaminu posłowie mogą zgłaszać przewodniczącemu posiedzenia: a) zastrzeżenia związane ze stwierdzeniem naruszenia przepisów regulujących przebieg posiedzenia; b) pytania związane z porządkiem obrad.

Poseł sygnalizuje przewodniczącemu chęć zgłoszenia zastrzeżenia lub zadania pytania przez podniesienie ręki. Przewodniczący udziela posłowi zgody na przedstawienie uwag, nie włączając jednak tego wystąpienia do porządku obrad. Przewodniczący niezwłocznie rozpatruje zgłoszone zastrzeżenie lub udziela odpowiedzi na zadane pytanie. W regulaminie Riigikogu nie ma postanowień dotyczących czasu przeznaczonego na zgłoszenie zastrzeżenia lub zadanie pytania związanego z porząadkiem obrad. Przepisy $\$ 74$ nie wskazują też liczby zastrzeżeń lub pytań, z jakimi mogą wystąpić posłowie.

\section{FINLANDIA - Eduskunta}

W regulaminie Eduskunty ${ }^{17}$ brak jest odrębnej kategorii „wniosków formalnych”, które można by uznać za odpowiednik wniosków formalnych w rozumieniu art. 184 regulaminu Sejmu.

Regulamin fińskiego parlamentu jest zwięzłym aktem prawnym (81 artykułów), ustanawia ogólne zasady pracy izby i jej organów oraz przebiegu procesu legislacyjnego. Niektóre czynności wymienione w art. 184 regulaminu Sejmu są unormowane także w regulaminie Eduskunty. Nie przynależą one jednak do szerszej kategorii stanowiącej odpowiednik sejmowych „wniosków formalnych” każda z tych czynności jest czynnością odrębną, funkcjonującą według trybu innego niż pozostałe. Na przykład kwestia tajności posiedzenia jest określona w art. 67 regulaminu Eduskunty, który stanowi, że jeśli przewodniczący Eduskunty uzna, że sprawa ze względu na swój charakter nie może stanowić przedmiotu jawnych obrad, lub jeśli 25 parlamentarzystów złoży wniosek o uchwalenie tajności obrad, przewodniczący Eduskunty zarządza usunięcie publiczności z galerii w sali posiedzeń, a Eduskunta rozstrzyga o tajności obrad.

\section{FRANCJA - Zgromadzenie Narodowe (I'Assemblée Nationale)}

Problematykę wniosków formalnych wyznacza art. 58 regulaminu Zgromadzenia Narodowego ${ }^{18}$. Wnioski formalne, a właściwie wnioski porządkowe (les rappels au Règlement) oraz wnioski o udzielenie głosu w sprawie prywatnej (les deman-

17 Parliament's Rules of Procedure (angielskie tłumaczenie aktu prawnego dostępne na stronie internetowej Eduskunty), https://www.eduskunta.fi/EN/naineduskuntatoimii/Documents/RulesofProcedure_20150416.pdf.

18 Règlement de l'Assemblée Nationale, http://www.assemblee-nationale.fr/connaissance/reglement.pdf. 
des de parole pour fait personnel) zawsze mają pierwszeństwo przed głównym pytaniem/tematem debaty i z mocy prawa wstrzymują przebieg debaty. Prawo głosu zostaje przyznane każdemu deputowanemu składającemu taki wniosek, od razu lub po zakończeniu przez niego wcześniejszej wypowiedzi ${ }^{19}$.

Wnioski formalne muszą być składane na podstawie przepisów regulaminu Zgromadzenia Narodowego. Jeżeli wniosek nie ma podstaw w regulaminie, ma na celu ponowne zakwestionowanie ustalonego porządku dnia lub dotyczy tej samej sprawy, w której zgłoszono już wniosek formalny, przewodniczący odbiera deputowanemu głos. Jeśli wielu deputowanych należących do tej samej grupy składa jednocześnie wnioski formalne, których celem jest zakwestionowanie ustalonego porządku dnia, przewodniczący może odmówić przyznania im głosu (art. 58 ust. 4 regulaminu). Wnioski o zawieszenie posiedzenia zależą od decyzji Zgromadzenia Narodowego, chyba że zgłoszone są przez rząd, przez przewodniczącego lub sprawozdawcę komisji, przez przewodniczącego grupy (klubu) lub osobę przez niego wyznaczoną (art. 58 ust. 5 regulaminu). W takich wypadkach wniosek jest skuteczny od razu, jednakże z tym ograniczeniem, że można z niego skorzystać maksymalnie dwa razy w ciągu trwania sesji podczas rozpatrywania tego samego tekstu (par séance au cours de l'examen d'un même texte), chyba że przewodniczący izby zadecyduje inaczej. Deputowany może uzyskać prawo głosu na maksymalnie 2 minuty (art. 58 ust. 6 regulaminu). Regulamin nie określa, ile wniosków z art. 58 regulaminu francuskiego Zgromadzenia Narodowego może złożyć deputowany. Regulamin nie określa też wyraźnej różnicy między wnioskami porządkowymi (formalnymi) a wnioskami w sprawach prywatnych. To regulują zwyczaje parlamentarne.

\section{HISZPANIA - Kongres Deputowanych (Congreso de los Diputados)}

$\mathrm{W}$ regulaminie Kongresu Deputowanych ${ }^{20}$ (Reglamento del Congreso de los Diputados) używa się przynajmniej czterech terminów na określenie polskiego „Wniosku” w rozumieniu prośby, żądania czy wezwania do zrobienia czegoś. Najczęściej używany jest termin solicitud (żądanie, prośba, wniosek). Zdarza się też użycie w dokładnie tym samym, jak się wydaje, znaczeniu terminu petición (prośba, wniosek, art. 76 regulaminu). Niekiedy używa się też terminu moción (wniosek). Jest tak w przypadku wniosku o wotum nieufności (moción de censura, art. 175 i n. regulaminu) czy też w przypadku wniosku o zajęcie przez izbę

19 „La parole est accordée à tout député qui la demande à cet effet soit sur-le-champ, soit, si un orateur a la parole, à la fin de son intervention".

20 Resolución de 24 de febrero de 1982 por la que se ordena la publicación en el „Boletín Oficial del Estado" del nuevo Reglamento del Congreso de los Diputados [TEXTO CONSOLIDADO. Última modificación: 7 de febrero de 2020], https://www.boe.es/buscar/ pdf/1982/BOE-A-1982-5196-consolidado.pdf; REGLAMENTO DEL CONGRESO DE LOS DIPUTADOS DE 10 DE FEBRERO DE 1982 [ostatnia zmiana: 5 lutego 2020], http://www.congreso.es/portal/page/portal/Congreso/Congreso/Hist_Normas/ Norm/reglam_congreso.pdf. 
stanowiska w sprawie interpelacji (art. 184 regulaminu). Czasem stosuje się też termin propuesta (propozycja, projekt), np. w przypadku wniosku o wotum zaufania (propuesta de confianza, art. 174.4 regulaminu) czy wniosków nominacyjnych (art. 204 i n. regulaminu).

Nie wyróżnia się w regulaminie hiszpańskiego Kongresu Deputowanych osobnej kategorii wniosków formalnych. Niemniej niektóre z przewidzianych w regulaminie wniosków można funkcjonalnie wyróżnić jako wnioski dotyczące spraw proceduralnych odnoszących się do porządku dziennego. Przez to spełniają one cechę definicyjną wniosku formalnego, tzn. są zgłaszane poza ustaloną kolejnością i dotyczą innych spraw niż kwestie merytoryczne związane z rozpatrywanym punktem porządku obrad. Tego rodzaju wnioski określane są w regulaminie ogólnym terminem solicitud lub - jeśli taki termin w odpowiednim przepisie nie pojawia się $\mathrm{w}$ formie rzeczownikowej lub zastąpiony jest zupełnie innym słowem - mogłyby być zapewne takim terminem określone.

Przykładami tego rodzaju wniosków są:

- wniosek o tajność obrad (solicitud de sesión secreta), art. 63.3 regulaminu ${ }^{21}$,

- wniosek (solicitud) deputowanego do Prezydium o pozwolenie mu na zdalne głosowanie elektroniczne (procedimiento telemático), art. 82.2 regulaminu $^{22}$,

- wniosek o głosowanie publiczne imienne lub głosowanie tajne (votación será pública por llamamiento o secreta cuando así [...] lo soliciten [...]), art. 85.1 regulaminu ${ }^{23}$,

- wniosek (petición) grupy parlamentarnej o zamknięcie debaty, art. 76 regula$\operatorname{minu}^{24}$,

- zmiana porządku dziennego na wniosek (a propuesta) przewodniczącego lub na wniosek (a petición) dwóch grup parlamentarnych lub 1/5 członków izby, art. 68.1 regulaminu.

W trakcie debaty żaden deputowany nie może zabierać głosu bez poproszenia o głos i udzielenie mu go przez przewodniczącego (art. 70.1 regulaminu).

21 Z inicjatywy Prezydium Kongresu, rządu, dwóch grup parlamentarnych lub 1/5 członków Kongresu.

22 Deputowany składa wniosek na piśmie, kierując go do Prezydium Izby, które powiadamia go o swojej decyzji.

${ }^{23}$ Głosowanie imienne lub tajne przeprowadzane jest w przypadkach przewidzianych regulaminem albo na wniosek dwóch grup parlamentarnych lub 1/5 deputowanych. W przypadku „zbiegnięcia się przeciwstawnych wniosków przeważa głosowanie tajne”. W żadnym wypadku nie może być przeprowadzone tajne głosowanie w postępowaniu ustawodawczym.

24 Debatę może zawsze zamknąć przewodniczący w porozumieniu z Prezydium, jeśli uzna, że sprawa została wystarczająco przedyskutowana. Zamknięcie debaty może nastąpić też na wniosek rzecznika grupy parlamentarnej. W sprawie takiego wniosku może zabrać głos tylko jeden mówca przeciwny wnioskowi i jeden popierający go, każdy z nich przez maksymalnie 5 minut. 
Dotyczy to również wniosków o charakterze formalnym przedstawionych wyżej, z wyjątkiem przykładu drugiego, w którym przewidziano explicite, że wniosek jest składany w formie pisemnej do Prezydium, a składający go nie uczestniczy osobiście w głosowaniu i, jak można przyjąć, również nie bierze osobiście udziału w debacie. Nie ma w regulaminie przepisu, który nakazywałby przewodniczącemu udzielenie głosu wnioskodawcom w pozostałych czterech przypadkach. Niemniej nie ma też w regulaminie przepisu, który jednoznacznie pozwalałby przewodniczącemu udzielać w tych przypadkach głosu w sposób dyskrecjonalny, co oznacza, że sposób działania przewodniczącego warunkowany jest kulturą parlamentarną, zwyczajami oraz aktualną sytuacją. Niezależnie jednak od sposobu działania decyzje przewodniczącego są szanowane, co jest elementem kultury parlamentarnej i prestiżu jego urzędu.

We wskazanych przypadkach wniosków o charakterze formalnym nie jest $\mathrm{w}$ regulaminie explicite określone ograniczenie czasowe wystąpienia wnioskodawców. Do ogólnych uprawnień przewodniczącego należy „zwiększanie lub redukowanie liczby i czasu wystąpień grup parlamentarnych i deputowanych, jak również akumulowanie - ze względu na okoliczności związane z grupami parlamentarnymi i materiami - wszystkich tych [wystąpień], które w określonej sprawie mogą odpowiadać jednej grupie parlamentarnej” (art. 73.2 regulaminu).

Nie ma w regulaminie specyficznego ograniczenia liczby składanych przez jeden podmiot (grupę parlamentarną lub deputowanego) wskazanych wyżej wniosków o charakterze formalnym.

\section{IRLANDIA - Zgromadzenie Irlandii (Dáil Éireann)}

W regulaminie Dáil Éireann ${ }^{25}$ brak jest odrębnej kategorii wniosków formalnych, które można by uznać za dokładny odpowiednik wniosków formalnych w rozumieniu art. 184 regulaminu Sejmu.

Pewne czynności wskazane w art. 184 regulaminu Sejmu są zawarte w regulaminie parlamentu irlandzkiego, jednak nie są to elementy składające się na kategorię stanowiącą odpowiednik polskich wniosków formalnych. Każda z tych czynności jest czynnością odrębną, funkcjonującą według trybu innego niż pozostałe. Na przykład kwestia zamknięcia dyskusji jest określona w art. 68 zatytułowanym „Zakończenie debaty” (Closure of debate), zgodnie z którym parlamentarzysta wnioskuje o zamknięcie dyskusji, wypowiadając formułę: That the question be now put (w wolnym tłumaczeniu: Już czas przejść do sprawy).

Jeżeli zdaniem przewodniczącego prowadzącego obrady taki wniosek nie narusza w żaden sposób regulaminu Dáil Éireann, jest on niezwłocznie realizowany, a decyzję podejmuje się bez debaty.

25 Standing Orders Relative to Public Business, https://data.oireachtas.ie/ie/oireachtas/ parliamentaryBusiness/standingOrders/dail/2019/2019-01-11_consolidated-dail-eireann-standing-orders-january-2019_en.pdf. 


\section{LUKSEMBURG - Izba Deputowanych (Chambre des députés)}

Regulamin Izby Deputowanych Luksemburga ${ }^{26}$ reguluje kwestie zgłaszania wniosków związanych z pracami Izby Deputowanych, tzw. wniosków porządkowych (des motions dordre), w art. 44. Postanowienia art. 44 regulaminu nie zawierają szczegółowego katalogu spraw, które mogą być adresowane w ramach wniosku porządkowego. Każdy poseł może w trakcie debaty poprosić o udzielenie mu głosu w ramach wniosku porządkowego, a procedura obejmuje następujące elementy:

- wniosek musi być podpisany przez przynajmniej 5 deputowanych,

- wniosek uznany za zgodny z regulaminem jest przedstawiany w czasie wyznaczonym przez przewodniczącego Izby; zgodnie z postanowieniami regulaminu Izby Deputowanych przewodniczący może uznać wniosek za niezgodny z regulaminem - jeżeli to postanowienie nie satysfakcjonuje wnioskodawcy, decyzję podejmuje Izba w formie głosowania (bez debaty, przez podniesienie rąk),

- w trakcie debaty nad wnioskiem porządkowym głos zabrać może wnioskodawca oraz po jednym członku każdej z grup czy kół politycznych,

- wnioskodawca ma 5 minut na wystąpienie, członkowie grup politycznych także mają na wystąpienie 5 minut, a członkowie kół politycznych - 2 minuty. Pewne kwestie, których przedmiot może stanowić odpowiednik spraw objętych wnioskiem formalnym określonym $\mathrm{w}$ art. 184 regulaminu Sejmu, przewidziano także w art. 41 regulaminu Izby Deputowanych Luksemburga dotyczącym tzw. pytań wstępnych (des questions préalables). Kategoria pytań wstępnych obejmuje m.in.:

- kwestie dotyczące tygodniowego porządku prac Izby,

- wnioski (une demande) o zmianę dziennego porządku obrad,

- wnioski (une demande) o głosowanie podzielone lub przerwanie głosowania,

- kwestie związane z odroczeniem obrad,

- uwagi o braku konieczności przeprowadzenia debaty,

- kwestie związane z przerwaniem i odroczeniem debaty.

Pytania wstępne są rozpatrywane przed zagadnieniem głównym debaty i nie są uwzględniane $\mathrm{w}$ obliczaniu przydzielonego posłom czasu wystąpień. Autor pytania ma 5 minut na wygłoszenie swojego wniosku i jego uzasadnienie, członkowie grup politycznych mają na wystąpienie 5 minut, a członkowie kół politycznych - 2 minuty. Jeżeli tematyka wygłaszanego wniosku nie dotyczy w rzeczywistości kwestii wskazanych w art. 41 regulaminu, przewodniczący odbiera posłowi głos. Jeżeli przewodniczący Izby uzna, że wygłaszane pytanie

26 Reglement de la chambre des deputes, 11 juillet 2019, https://www.chd.lu/wps/wcm/ connect/public/5abf3456-f398-4259-a831-20788c0f208c/reglementjuli2019.pdf?MO $\mathrm{D}=\mathrm{AJPERES} \&$ ContentCache $=\mathrm{NONE} \& \mathrm{CACHE}=\mathrm{NONE} \& \mathrm{CVID}=\mathrm{mOb} 0 \mathrm{p} 1 \mathrm{~W} \& \mathrm{CVI}$ $\mathrm{D}=\mathrm{mOb} 0 \mathrm{p} 1 \mathrm{~W}$. 
wstępne zawierające wniosek o odroczenie obrad ma w istocie na celu jedynie utrudnienie prac parlamentu, może je niezwłocznie (bez debaty) poddać pod głosowanie.

W regulaminie Izby Deputowanych nie zawarto przepisów określających liczbę składanych wniosków porządkowych czy pytań wstępnych. Regulamin nie zawiera też bezpośredniego wskazania dotyczącego obligatoryjności lub fakultatywności decyzji przewodniczącego Izby w sprawie udzielenia posłowi głosu w celu złożenia wniosku porządkowego lub pytania wstępnego. Co do zasady (art. 36 regulaminu), żaden poseł nie może zabrać głosu, dopóki w tym celu nie zarejestruje się lub nie wystąpi z odpowiednią prośbą do przewodniczącego Izby i nie uzyska jego zgody.

\section{ŁOTWA - Saeima}

W regulaminie Saeimy ${ }^{27}$ występują dwie kategorie wniosków, które można uznać za odpowiedniki wniosków formalnych w rozumieniu art. 184 regulaminu Sejmu.

W pierwszym przypadku uregulowania łotewskiej Saeimy odnoszą się do kwestii zabierania głosu podczas posiedzenia. Zgodnie z postanowieniami regulaminu prawo do zabrania głosu poza kolejnością może zostać przyznane mówcy, który odnosi się do nieprzestrzegania regulaminu izby lub wypowiada się na temat sposobu dalszego procedowania danej sprawy (art. 66). Zgodnie z art. 67 mówca, który chciałby wystąpić z pilną wypowiedzią poza porządkiem obrad, musi uprzednio wskazać w pisemnym wniosku temat swojego wystąpienia. Decyzję o udzieleniu głosu w tym wypadku podejmuje przewodniczący posiedzenia; w razie uzyskania zgody czas wypowiedzi nie może przekroczyć 3 minut. Według art. 56 ust. 1 regulaminu zgoda na zabranie głosu z mównicy udzielana jest przez przewodniczącego, po uprzednim otrzymaniu wniosku w tej sprawie prośby o zabranie głosu mogą być zgłaszane na piśmie lub przy wykorzystaniu elektronicznego systemu głosowania. Artykuł 56 ust. 1 określa katalog osób, które mogą zabrać głos bez pisemnego wniosku (wśród nich znajdują się m.in: sprawozdawca; mówcy biorący udział w debacie nad projektem ustawy lub projektem uchwały; osoby udzielające odpowiedzi na pytanie).

Niektóre kwestie wymienione w art. 184 regulaminu Sejmu, czyli postanowienia dotyczące zgłaszania wniosków związanych z przedmiotem porządku dziennego i przebiegu posiedzenia, zostały uregulowane w regulaminie Saeimy w sposób odmienny od konstrukcji klasycznego wniosku formalnego, co przejawia się m.in. w kolektywnej formule ich zgłaszania (w większości przypadków). Do takich przypadków należą na przykład wnioski w sprawach:

${ }^{27}$ Informacja przygotowana na podstawie regulaminu Saeimy w języku angielskim, który jest dostępny na stronie łotewskiego parlamentu pod adresem: https://www. saeima.lv/en/about-saeima/work-of-the-saeima/rules-of-procedure/. 
- zawieszenia lub zamknięcia posiedzenia - z wyjątkiem określonych przypadków posiedzenie może zostać zawieszone i zamknięte tylko na podstawie decyzji podjętej przez Saeimę; o zawieszenie lub zamknięcie posiedzenia może wnioskować przewodniczący posiedzenia lub co najmniej 5 posłów (art. 49),

- ograniczenia czasu wystąpień i zamknięcia listy mówców - na wniosek co najmniej 10 posłów Saeima może postanowić o skróceniu czasu wystąpień lub zamknięciu listy mówców (art. 65 ust. 1),

- zamknięcia debaty - na wniosek co najmniej 20 posłów Saeima może zadecydować o zamknięciu debaty (art. 65 ust. 5),

- uchwalenia tajności obrad - na wniosek złożony przez m.in. 10 posłów, Saeima może zadecydować większością co najmniej 2/3 głosów obecnych posłów o utajnieniu posiedzenia (art. 77).

W powyższych sytuacjach decyzja podejmowana jest w drodze głosowania, przy czym tylko dwóch posłów ma możliwość zabrania głosu przed głosowaniem (wystąpienia nie mogą przekroczyć 5 minut) - poseł popierający wniosek oraz poseł przeciwny temu wnioskowi (art. 54).

Zgodnie z art. 47 regulaminu Saeimy przewodniczący obradom może, według własnego uznania lub na wniosek 5 posłów, ogłosić rejestrację posłów $\mathrm{w}$ celu stwierdzenia kworum.

W regulaminie Saeimy nie zawarto przepisów określających liczbę składanych wniosków związanych z przedmiotem porządku dziennego i przebiegu posiedzenia.

\section{NIDERLANDY - Izba Reprezentantów (Tweede Kamer)}

$\mathrm{W}$ regulaminie Izby Reprezentantów ${ }^{28}$ przewidziano odrębną kategorię wniosków formalnych (point/matter of order), jednak nie zawarto jej definicji ani katalogu spraw mogących być przedmiotem takiego wniosku. W art. 56 regulaminu Izby Reprezentantów stwierdza się jedynie, że porządek wystąpień może zostać przerwany m.in. wtedy, gdy deputowany zgłosi wniosek formalny. Wniosek formalny może zostać zgłoszony przez przewodniczącego Izby lub deputowanego. Ponadto zgodnie z art. 63 regulaminu Izby Reprezentantów czas wystąpienia w ramach wniosków formalnych nie jest wliczany do czasu wystąpień przewidzianego dla wystąpień na dany temat. W regulaminie Izby Reprezentantów nie zawarto przepisów określających liczbę składanych wniosków formalnych.

Jednocześnie niektóre kwestie wymienione w art. 184 regulaminu Sejmu, czyli postanowienia dotyczące zgłaszania wniosków związanych z przedmiotem porządku dziennego i przebiegu posiedzenia, zostały uregulowane $\mathrm{w}$ regulaminie Izby Reprezentantów odrębnie, np.:

28 House of Representatives of the Netherlands - Rules of Procedure, June 2018, https:// www.houseofrepresentatives.nl/sites/default/files/atoms/files/180626-reglement_ van_orde_engels.pdf. 
- w art. 67 przewidziano, że deputowany obecny na posiedzeniu może wnioskować (propose) o zamknięcie dyskusji; wniosek taki nie jest uzasadniany i nie podlega debacie,

- w art. 68 przewidziano, że deputowany obecny na posiedzeniu może wnioskować (propose) o zamknięcie dyskusji w określonym czasie; wniosek taki nie podlega debacie,

- w art. 90 i 119 uregulowano kwestie kierowania projektów ustaw lub innych dokumentów do właściwych komisji przez przewodniczącego, pierwszego wiceprzewodniczącego i drugiego wiceprzewodniczącego; jeśli decyzja taka nie była podjęta przez nich jednomyślnie, projekt ustawy lub inny dokument nie może zostać skierowany do komisji dopóki informacja o tym nie zostanie przekazana na publicznym posiedzeniu Izby Reprezentantów; Izba Reprezentantów może podjąć inną decyzję; wniosek w tej sprawie może złożyć każdy deputowany.

\section{NIEMCY - Bundestag}

Kwestie związane ze składaniem w Bundestagu wniosków odpowiadających kategorii wniosku formalnego, o którym mowa w regulaminie Sejmu, zostały określone przede wszystkim w $\$ 29$ regulaminu wewnętrznego niemieckiego Bundestagu ${ }^{29}$. Paragraf 29 regulaminu Bundestagu odnosi się do zgłaszania tzw. wniosków dotyczących porządku obrad (Geschäftsordnungsantrag), a także wniosków dotyczących przebiegu posiedzenia czy przedmiotu debaty, zgłaszanych w trakcie trwania posiedzenia. Takie wnioski można określić jako wnioski porządkowe. Wniosek porządkowy wskazany w regulaminie w odniesieniu do wybranych czynności odpowiada więc w dużym stopniu kategorii wniosku formalnego $\mathrm{z}$ art. 184 regulaminu Sejmu ${ }^{30}$.

Wnioski porządkowe traktowane są w Bundestagu jako te, które nie zostały zgłoszone i przyjęte do porządku dziennego zgodnie z regulaminem. Ta kwestia została uregulowana w $\$ 20$ regulaminu, zatytułowanym Tagesordnung (porządek dzienny).

W kolejnych punktach $\$ 29$ regulaminu Bundestagu stwierdzono:

- przewodniczący Bundestagu nadaje pierwszeństwo każdemu wnioskowi w sprawie wniosku porządkowego; wniosek taki musi dotyczyć przedmiotu debaty lub porządku obrad,

- przewodniczący może ograniczyć liczbę wniosków dotyczących porządku obrad do wniosku przedstawionego przez jednego wnioskodawcę, o ile treści tych wniosków pokrywają się; w razie zgłoszenia wielu różnych wniosków, wnioski takie przedstawiają rzecznicy frakcji parlamentarnych,

29 Regulamin porządku obrad niemieckiego Bundestagu (Geschäftsordnung des Deutschen Bundestages) [tłumaczony także jako Regulamin wewnętrzny niemieckiego Bundestagu], https://www.gesetze-im-internet.de/btgo_1980/_29.html.

30 Komentarz do Regulaminu Sejmu Rzeczypospolitej Polskiej, red. A. Szmyt, Warszawa 2018. 
- jeżeli członek Bundestagu wypowiada się w sprawie porządku obrad, nie zgłaszając, że chce mówić w tej sprawie lub nie chcąc wystąpić z wnioskiem dotyczącym porządku obrad, przewodniczący udziela mu głosu według własnego uznania,

- indywidualny mówca nie może wypowiadać się w sprawie porząaku obrad dłużej niż 5 minut.

W regulaminie Bundestagu nie stworzono zamkniętego katalogu spraw, w których mogą być zgłaszane wnioski formalne (porządkowe) ${ }^{31}$. Prawo do zgłaszania wniosków porządkowych należy do członków Bundestagu (parlamentarzystów), a także do rzeczników poszczególnych frakcji, którzy reprezentują poszczególne grupy parlamentarzystów.

Zaznaczyć należy, że zgodnie $\mathrm{z} \$ 20$ ust. 1 regulaminu termin i porządek obrad każdego posiedzenia Bundestagu ustalane są przez Radę Seniorów (Ältestenrat ${ }^{32}$ ), chyba że Bundestag zadecyduje o nim wcześniej lub przewodniczący ustali je samodzielnie, na podstawie $\$ 21$ ust. $1^{33}$.Zgodnie $\mathrm{z} \$ 20$ ust. 3, jeżeli przewodniczący samodzielnie zaplanował posiedzenie w innych sprawach lub uzupełnił porządek obrad, musi uzyskać zgodę Bundestagu ${ }^{34}$ na te zmiany na początku posiedzenia.

Zgodnie $\mathrm{z} \$ 20$ ust. 2 porządek obrad jest przekazywany członkom Bundestagu, Bundesratu oraz członkom Rządu Federalnego. Jeżeli nie ma sprzeciwu, uważa się, że został on przyjęty w momencie wywołania punktu pierwszego. Każdorazowo po otwarciu posiedzenia plenarnego, ale przed przejściem do porząaku dziennego każdy poseł do Bundestagu może wnieść o zmianę porządku obrad. Musi przy tym wcześniej przedłożyć wniosek w tej sprawie u przewodniczącego do godziny 18:00 dnia poprzedniego.

Zgodnie z $\$ 20$ ust. 3 po ustaleniu porządku obrad inne sprawy winny być omawiane tylko wtedy, gdy: sprzeciwu nie wniesie grupa 5 ze 100 obecnych na posiedzeniu członków Bundestagu, sprzeciwu nie wniesie jedna $\mathrm{z}$ frakcji lub jeśli regulamin dopuszcza możliwość dyskusji poza porządkiem obrad. Bundestag może w każdej chwili usunąć punkt z porządku obrad.

31 Komentarz do Regulaminu Sejmu Rzeczypospolitej Polskiej, red. A. Szmyt, op. cit., s. 834.

32 Ältestenrat (Rada Seniorów) składa się z przewodniczącego Bundestagu, jego zastępców i 23 innych, doświadczonych deputowanych. Rada doradza przewodniczącemu Bundestagu w jego pracy oraz zapewnia skoordynowany i płynny przebieg prac w Bundestagu. Na przykład (w dłuższej perspektywie) ustala terminy posiedzeń, a następnie na bieżąco uzgadnia porządek obrad. Rada Seniorów to także miejsce, gdzie dyskutuje się i rozstrzyga spory.

33 Przewodniczący samodzielnie ustala termin i porządek obrad, jeżeli upoważni go do tego Bundestag albo wtedy, gdy z jakiegoś powodu takie upoważnienie nie może być wydane.

34 Zgodnie z artykułem 42 ust 2 niemieckiej Ustawy Zasadniczej decyzje w Bundestagu są podejmowane większością oddanych głosów, o ile Ustawa Zasadnicza nie stanowi inaczej. 


\section{PORTUGALIA - Zgromadzenie Republiki (Assembleia da República)}

Regulamin Zgromadzenia Republiki (Regimento da Assembleia da República) ${ }^{35}$ nie przewiduje odrębnej kategorii wniosków formalnych. Niemniej w rozdziale poświęconym obradom plenarnym stanowi się, że „deputowanym udzielany jest głos” w kilkunastu przypadkach, wśród których wymienia się 3 o charakterze wniosków formalnych. Są to: powołanie się na regulamin lub interpelacja czy też zapytanie do Prezydium (invocar o Regimento ou interpelar a Mesa), przedstawienie wezwania (fazer requerimentos) i złożenie odwołania czy też skargi (interpor recursos) (art. 76.1, odpowiednio litery f, g, j).

Deputowani mogą interpelować do Prezydium, gdy mają wątpliwości co do jego decyzji lub co do kierunku prac. Deputowany, proszący o głos w celu powołania się na regulamin, wskazuje normę, która została naruszona, oraz zgłasza niezbędne uwagi. Wystąpienie w celu powołania się na regulamin lub przedstawienie interpelacji nie może przekraczać 2 minut (art. 80).

Jako wezwania do Prezydium dopuszczalne są jedynie wnioski czy też żądania (pedidos) dotyczące procedury przedstawiania, dyskusji i głosowania jakiejkolwiek sprawy lub też funkcjonowania posiedzenia. Wezwania można zgłaszać na piśmie bądź ustnie. Wezwania pisemne są bezzwłocznie ogłaszane przez Prezydium i dystrybuowane między grupami parlamentarnymi. Wezwania ustne, jak również lektura wezwań pisemnych, jeśli się jej zażąda, nie mogą przekraczać 2 minut. Wezwanie, po jego przyjęciu, jest niezwłocznie głosowane bez debaty. Głosowania nad wezwaniami odbywa się w kolejności ich zgłoszenia (art. 81 regulaminu). Zgodnie z innym artykułem regulaminu do przewodniczącego Zgromadzenia należy w szczególności „przyjmowanie lub odrzucanie [...] wezwań, po weryfikacji ich poprawności regulaminowej, bez uszczerbku do prawa odwołania się [recurso] do Zgromadzenia” (art. 16.1 lit. C regulaminu).

Każdy deputowany może składać zażalenie (reclamar) na decyzję przewodniczącego Zgromadzenia lub Prezydium lub odwoływać się (recorrer) od nich do plenum Zgromadzenia. Deputowany, który złożył odwołanie, ma prawo zabrać głos w celu jego uzasadnienia w czasie nieprzekraczającym 3 minut. W przypadku odwołania przedstawionego przez więcej niż jednego deputowanego, z uzasadnieniem wystąpić może tylko jeden z nich, niezależnie od tego, czy należą do tej samej grupy parlamentarnej, czy nie. W przypadku wielu odwołań dotyczących tego samego przedmiotu wystąpić z uzasadnieniem może tylko jeden deputowany z każdej z grup parlamentarnych, do których należą wnioskodawcy. Ponadto głos może zabrać przez czas nie dłuższy niż 3 minuty deputowany z każdej grupy parlamentarnej, która nie składała odwołania w danej sprawie (art. 82).

W czasie posiedzeń plenarnych do kompetencji przewodniczącego Zgromadzenia należy „udzielanie głosu deputowanym i członkom rządu oraz zapewnia-

35 Regimento da Assembleia da República, Assembleia da República, https://www.parlamento.pt/Legislacao/Documents/Legislacao_Anotada/RegimentoAR_Simples.pdf. 
nie porząaku w obradach” (art. 17.1 lit b regulaminu). Jednocześnie „od decyzji przewodniczącego Zgromadzenia podjętych $\mathrm{w}$ trakcie posiedzenia plenarnego zawsze przysługuje zażalenie [reclamação], jak również odwołanie [recurso] do plenum Zgromadzenia" (art. 17.3).

\section{SŁOWACJA - Rada Narodowa (Národná Rada)}

Regulamin słowackiej Rady Narodowej ${ }^{36}$ zna kategorię osobnego wniosku formalnego pod nazwą wniosku porządkowego lub proceduralnego (procedurálny návrh). Przepisy art. 34 regulaminu nie tylko przewidują ten rodzaj wniosku, ale również określają go przedmiotowo, stanowiąc, że członkowie Rady Narodowej mają prawo złożenia wniosku porządkowego, dotyczącego trybu rozpatrywania danej sprawy, terminów i innych kwestii związanych z metodą pracy izby. Wniosek porządkowy składany jest poza kolejnością mówców, a czas na jego zgłoszenie nie może przekroczyć 2 minut. Wniosek taki jest przedstawiany ustnie, niemniej wymaga niezwłocznego (bezprostredne) przedstawienia go przewodniczącemu izby również w formie pisemnej. Nad wnioskiem porządkowym głosuje się bez dyskusji ( $\$ 38$ ust. 1). Regulamin słowackiej Rady Narodowej dopuszcza jednocześnie możliwość niepoddania wniosku porządkowego pod głosowanie. Wymaga to jednak, aby wniosek taki miał „oczywiste poparcie” (zrejmú podporu) całej izby. W takim przypadku przewodniczący Rady Narodowej zwraca się z pytaniem, czy ktoś ma jakąś uwagę (sprzeciw) co do wniosku. Brak uwagi, względnie uwaga tylko jednego posła oznacza przyjęcie wniosku bez głosowania. Z kolei nad wnioskami, które nie mają oczywistego poparcia (ktorý nemá zrejmú podporu), głosuje się niezwłocznie. Jednocześnie regulamin przewiduje, że wnioski porządkowe, które zostały zgłoszone w sytuacji, gdy analogiczne wnioski zostały przez izbę wcześniej odrzucone, pozostają bez rozpatrzenia. Obok ogólnej kategorii wniosków porządkowych przepisy $\$ 39$ przewidują również szczególną postać tego rodzaju wniosku, jaką jest „protest przeciwko wynikowi głosowania z powodu awarii urządzeń technicznych do liczenia głosów" (námietku proti výsledku hlasovania $z$ dôvodu nefunkčnosti technického zariadenia). Protest w tej sprawie może zgłosić każdy poseł. W takiej sytuacji Rada rozstrzyga o wniosku w głosowaniu, a przyjęcie wniosku oznacza konieczność powtórzenia głosowania. Innym szczególnym wnioskiem proceduralnym, przewidzianym $\mathrm{w} \$ 39$ regulaminu, jest wniosek o przeprowadzenie głosowania tajnego. Wniosek taki może zgłosić grupa co najmniej 15 posłów. Jednocześnie wniosek musi zostać zgłoszony w określonym czasie, tj. nie później niż do rozpoczęcia dyskusji w sprawie, która miałaby być objęta głosowaniem tajnym.

36 Rokovací poriadok Národnej rady Slovenskej republiky, https://www.nrsr.sk/web/ Static/sk-SK/NRSR/Doc/zd_rokovaci-poriadok-20190821.pdf. 


\section{SZWECJA - Riksdag}

Regulamin Riksdagu (Riksdagsordningen 2014:801, The Riksdag Act 2014:801 ${ }^{37}$ ) nie przewiduje kategorii wniosków formalnych, które stanowiłyby odpowiednik wniosków formalnych sprecyzowanych w regulaminie polskiego Sejmu.

Ogólne uregulowanie zawarte w art. 15 rozdz. 6 regulaminu Riksdagu, dotyczące prawa do zabierania głosu, stanowi, że każdy członek Riksdagu i każdy minister ma prawo do swobodnego wypowiadania się na posiedzeniu we wszystkich sprawach będących przedmiotem obrad oraz w sprawie legalności wszystkiego, co ma miejsce na posiedzeniu. Zgodnie $\mathrm{z}$ art. 16 rozdz. 6 osoba zabierająca głos ogranicza swoje wystąpienie do kwestii, które są przedmiotem dyskusji. W sytuacji, w której mówca nie stosuje się do tego ograniczenia oraz do upomnień przewodniczącego, przewodniczący izby może pozbawić go głosu.

Przewodniczący izby ustala kolejność wystąpień mówców podczas debaty na posiedzeniu plenarnym, spośród tych, którzy przed przystąpieniem do omawiania danej sprawy zawiadomią o chęci zabrania głosu; posłowie proszący o pozwolenie na zabranie głosu podczas obrad zabierają głos w takiej kolejności, w jakiej poinformowali o chęci zabrania głosu. Niezależnie od ustalonej kolejności mówców i bez uprzedzenia, przewodniczący izby może udzielić głosu m.in. posłowi, który wcześniej zabierał głos, w celu ustosunkowania się do wystąpienia poprzedniego mówcy (art. 22 rozdz. 6).

\section{WŁOCHY - Izba Deputowanych (Camera dei Deputati)}

Regulamin włoskiej Izby Deputowanych (Il Regolamento della Camera) ${ }^{38}$ w rozdz. VIII pt. „O dyskusji” (della Discussione) w części pierwszej obszernie reguluje problematykę wystąpień z wnioskami o charakterze formalnym. Regulamin nie posługuje się przy tym jednym wspólnym określeniem na wnioski formalne i najczęściej typizuje je w zależności od tego, czego dotyczą (np. wniosek o przestrzeganie regulaminu, wniosek w sprawie sposobu głosowania). Zarazem art. 36 ust. 3 regulaminu wyraźnie postanawia, że żaden deputowany nie może zabrać głosu bez zgody przewodniczącego Izby (Nessuno può parlare senza il permesso del Presidente). Regulamin Izby Deputowanych wyodrębnia zasadniczo dwa rodzaje wniosków, którym przypisać można formalny charakter.

Pierwszym są tzw. pytania wstępne (la questione pregiudiziale), unormowane $\mathrm{w}$ art. 40 regulaminu. Obejmują one trzy kluczowe kwestie proceduralne, tj. wniosek o to, aby dane zagadnienie nie było dyskutowane w czasie posiedzenia (quella cioè che un dato argomento non debba discutersi), wniosek o przesunięcie danego punktu porządku obrad (quella cioè che la discussione debba rinviarsi) i wnio-

37 Informacja sporządzona na podstawie angielskiego tłumaczenia regulaminu Riksdagu, które jest dostępne pod adresem: https://www.riksdagen.se/globalassets/07.-dokument--lagar/the-riksdag-act-2015.pdf.

38 Https://www.camera.it/leg18/437? conoscerelacamera=237. 
sek o zawieszenie posiedzenia (questione sospensiva). Wniosek taki (a właściwie pytanie wstępne) może zgłosić każdy deputowany przed rozpoczęciem danego punktu porządku obrad. Jeśli dany punkt zaczął już być rozpatrywany, złożenie pytania wstępnego jest dopuszczalne, ale pod warunkiem, że podpisze się pod nim minimum 10 deputowanych, w tym co najmniej 3 z komisji, która zajmowała się daną sprawą. Przedstawienie pytania i jego uzasadnienie może trwać nie dłużej niż 10 minut, a cała dyskusja nad nim nie dłużej niż 5 minut.

Drugim rodzajem wniosków formalnych są wnioski, o których stanowi art. 41 regulaminu. Obejmują one różne kwestie, w tym np. wniosek o przestrzeganie regulaminu (richiami al Regolamento), wniosek dotyczący porządku dziennego posiedzenia (per l'ordine del giorno o per l'ordine dei lavori), wniosek o kolejność głosowania (per la priorità delle votazioni). Wszystkie te wnioski mają pierwszeństwo przed innymi. Deputowany składa wniosek ustnie i w dyskusji nad nim może wystąpić jeden oponent wniosku. Każdy z mówców wypowiadających się w sprawie wniosku ma maksymalnie 5 minut na wystąpienie. Dysponentem wniosku, zgodnie z art. 41 ust. 1, jest przewodniczący Izby, który, jeśli uzna za stosowane, poddaje wniosek pod głosowanie. W takim wypadku głosowanie odbywa się przez podniesienie ręki (bez udziału elektronicznego systemu liczenia głosów).

Artykuł 43 regulaminu Izby Deputowanych wyłącza wszystkie wystąpienia na podstawie art. 40 i 41 z generalnej zasady ograniczającej możliwość zabrania głosu przez deputowanego w danym punkcie porządku obrad tylko do jednego razu. Z wyłączenia tego korzystają też tzw. wypowiedzi osobiste deputowanego, przewidziane w art. 42 regulaminu. Dotyczą one sytuacji, w których błędnie przywołano wypowiedź deputowanego lub ją źle zinterpretowano albo zniekształcono. W takim wypadku deputowany może zabrać dodatkowo głos, ale w pierwszej kolejności musi wskazać, na czym polega jej osobisty charakter (la parola deve indicare in che consiste il fatto personale).

\section{STANY ZJEDNOCZONE - Izba Reprezentantów (House of Representatives)}

Zgodnie z postanowieniami regulaminu Izby Reprezentantów Stanów Zjednoczonych $^{39}$ członkowie Izby dysponują możliwością zgłoszenia wniosków lub żądań, które pozwalają im np. na zgłoszenie naruszenia regulaminu czy na wnioskowanie o przeprowadzenie głosowania imiennego. W regulaminie brak jest odrębnej kategorii wniosków formalnych, które można by uznać za odpowiednik wniosków formalnych w rozumieniu art. 184 regulaminu Sejmu, jednak wybrane narzędzia, którymi dysponują członkowie Izby, odpowiadają pewnym czynnościom czy też zakresom spraw wskazanym w art. 184 regulaminu Sejmu.

39 Rules of the House of Representatives for the 116th Congress, 11.01.2019, https://rules. house.gov/sites/democrats.rules.house.gov/files/documents/116-House-Rules-Clerk.pdf. 
Wszystkie wnioski (motions), które są składane przez członków Izby Reprezentantów, są skuteczne wyłącznie po zatwierdzeniu (w drodze głosowania) przez Izbę. Ponadto członkowie mogą także zgłaszać żądania (requests), w sprawach, w których nie rozstrzyga się w drodze głosowania, ale decyzję podejmuje przewodniczący Izby lub wymagana jest zgoda izby (np. żądanie wykreślenia $\mathrm{z}$ debaty wypowiedzi innego członka Izby) ${ }^{40}$.

W większości przypadków wniosek lub żądanie mogą być złożone przez każdego członka Izby, który ma głos lub któremu zgody na złożenie udzielił przewodniczący obrad. Wnioski wymagające przeprowadzenia debaty podlegają ogólnym regułom czasowym debat w Izbie Reprezentantów, a debata rozpoczyna się po odczytaniu wniosku. W przypadku większości wniosków każdy członek Izby może zażądać przedstawienia wniosku w formie pisemnej. Zwyczajowo wnioski o odroczenie obrad, a także żądania są składane w formie ustnej ${ }^{41}$.

Jako pewnego rodzaju odpowiedniki czynności wymienionych w art. 184 regulaminu Sejmu wskazać można m.in. następujące wnioski sformułowane w regulaminie Izby Reprezentantów USA, składane w trakcie debaty w Izbie, przedstawione według kolejności ich zgłaszania i rozpatrywania (zgodnie z postanowieniami działu [Rule] XVI, pkt 4(a) regulaminu izby):

- wniosek o odroczenie obrad Izby (motion to adjourn, w sprawie wniosku o odroczenie nie przeprowadza się debaty),

- wniosek o przełożenie rozpatrywania na inny dzień (motion to postpone to a day certain, wniosek taki nie może być złożony w danej sprawie ponownie tego samego dnia na tym samym etapie procedury),

- wniosek o odroczenie rozpatrywania na czas nieokreślony (motion to postpone indefinetly, wniosek taki nie może być złożony w danej sprawie ponownie tego samego dnia na tym samym etapie procedury).

W regulaminie Izby Reprezentantów wskazano także inne czynności mogące stanowić odpowiednik wniosków formalnych, z których każda funkcjonuje według odrębnego, indywidualnego trybu. Jako przykłady wskazać można:

- wniosek o ponowne rozpatrzenie przez Izbę kwestii, nad którą przeprowadzono już głosowanie (motion to reconsider), uregulowano $\mathrm{w}$ dziale XIX (Rule XIX), pkt 3 i 4; wniosek taki złożyć może członek Izby, który głosował tak jak większość, w tym samym dniu, w którym odbyło się głosowanie lub dzień po głosowaniu,

- wniosek o przeprowadzenie głosowania imiennego (motion for recorded vote, dział XX [Rule XX], pkt 1(b)), który wymaga od wnioskodawcy uzyskania poparcia $1 / 5$ kworum (44 członków Izby),

40 Ch.M. Davis, Commonly Used Motions and Requests in the House of Representatives. Report prepared for Members and Committees of Congress, Congressional Research Service, 16.09.2015, s. 1; https://fas.org/sgp/crs/misc/RL32207.pdf.

41 Ch.M. Davis, Commonly Used Motions, op. cit., s. 2. 
- wniosek o przerwanie debaty i przeprowadzenie głosowania w danej sprawie (motion for the previous question, dział XIX [Rule XIX], pkt 1); jeżeli wniosek został złożony w sprawie, co do której regulamin przewiduje debatę, a takiej debaty nie przeprowadzono przed wpłynięciem wniosku, przed głosowaniem należy odbyć debatę trwającą 40 minut (równo podzielonych między wnioskodawcę i jego oponenta); wniosek o przerwanie debaty i głosowanie uniemożliwia np. zgłaszanie dalszych poprawek lub wniosków do danej kwestii będącej przedmiotem obrad ${ }^{42}$,

- wniosek o odesłanie sprawy do ponownego rozparzenia przez komisję lub komisje (dział XIX [Rule XIX], pkt 2) może być tzw. wnioskiem prostym (motion to recommit) lub wnioskiem $\mathrm{z}$ instrukcjami (motion to recommit with instructions); wniosek o odesłanie do komisji składany jest przed ostatecznym głosowaniem w sprawie przyjęcia danego środka, a pierwszeństwo w sprawie jego złożenia przewodniczący obrad przyznaje członkowi Izby, który jest przeciwko debatowanej kwestii; ewentualne instrukcje dołączone do wniosku mogą zawierać wyłącznie nakaz, aby komisja niezwłocznie zgłosiła Izbie wszelkie proponowane poprawki.

Ponadto członkowie Izby Reprezentantów mogą zgłaszać tzw. uwagi porządkowe (points of order), będące twierdzeniem (wygłaszanym $\mathrm{z}$ sali), że w danym momencie naruszono regulamin Izby. Przewodniczący obrad udziela pierwszeństwa głosu członkowi, który chce wystąpić z uwagą porządkową i który musi dokładnie wskazać naruszony przepis regulaminu ${ }^{43}$. Zgodnie z postanowieniami działu I (Rule I), pkt 5, przewodniczący Izby rozstrzyga wszystkie uwagi porządkowe, a członkowie Izby mogą się od jego decyzji odwołać. W sprawie odwołania się od danej decyzji dotyczącej zgłoszonej uwagi porządkowej członek Izby może przemawiać bez zgody Izby tylko raz. We wskazanych w regulaminie Izby sytuacjach i pod określonymi warunkami przewodniczący może odmówić przyjęcia uwagi porządkowej, np. w przypadku uwagi dotyczącej braku kworum podczas debaty ogólnej (dział [Rule] XVIII, pkt 6(b) regulaminu Izby).

\section{WIELKA BRYTANIA - Izba Gmin (House of Commons ${ }^{44}$ )}

W brytyjskiej Izbie Gmin jej członkowie uprawnieni są do zgłaszania uwag formalnych (point of order). W regulaminie Izby Gmin (Standing Orders of the House of Commons $)^{45}$ nie ma odrębnego artykułu regulującego uwagi formalne.

Uwaga formalna jest wnioskiem do przewodniczącego o wyjaśnienie lub rozstrzygnięcie kwestii proceduralnej w Izbie Gmin. Członek Izby Gmin przedstawia

42 Ibidem, s. 8.

43 Ibidem, s. 5.

44 Https://www.parliament.uk/business/commons/.

45 Https://publications.parliament.uk/pa/cm201919/cmstords/341/so_341_051119_ web.pdf. 
powody, dla których uważa, że regulamin Izby został naruszony, a przewodniczący podejmuje decyzję w tej sprawie ${ }^{46}$. W Przewodniku dotyczącym procedury dla członków Izby Gmin (MPs' Guide to Procedure) wskazano, że deputowany może zgłosić uwagę formalną dotyczącą danego zdarzenia w każdej chwili bezpośrednio po tym zdarzeniu, wygłaszając formułę: On a point of order, Mr Speaker. Inne uwagi formalne, niezwiązane $\mathrm{z}$ daną debatą lub wystąpieniem innego parlamentarzysty, zwykle są zgłaszane po czasie przeznaczonym na pytania, pytania w sprawach pilnych lub oświadczenia ustne ${ }^{47}$. Nie przewidziano ograniczenia ilościowego ani czasowego dotyczącego zgłaszania przez członka Izby Gmin uwag formalnych.

Ponadto pewne czynności wskazane w art. 184 regulaminu Sejmu są odrębnie unormowane w regulaminie parlamentu brytyjskiego, jednak nie składają się na jedną kategorię wniosków. Na przykład: a) złożenie wniosku o tajność posiedzenia Izby lub komisji uregulowano w art. 163 zatytułowanym „Wnioski o tajność posiedzenia" (Motions to sit in private), przy czym wniosek taki może zostać zgłoszony tylko raz podczas posiedzenia ${ }^{48}$; b) kwestia zamknięcia dyskusji jest określona w art. 36 zatytułowanym „Zakończenie debaty” (Closure of debate), zgodnie z którym parlamentarzysta wnioskuje o zamknięcie dyskusji, wypowiadając w pozycji stojącej ze swojego miejsca wskazaną formułę ${ }^{49}$.

\section{PARLAMENT EUROPEJSKI}

W Parlamencie Europejskim (dalej: Parlament lub PE) istnieje kilka rodzajów wniosków, które zbliżają się w swojej postaci do polskiego wniosku formalnego $\mathrm{z}$ art. 184 regulaminu Sejmu. Warto wspomnieć, że w regulaminie $\mathrm{PE}^{50}$ istnieje bardzo rozbudowana systematyka wniosków formalnych, czego potwierdzeniem jest okoliczność uregulowania całości zagadnienia dotyczącego wniosków formalnych w osobnym rozdziale szóstym regulaminu pt. „Wnioski w sprawie przestrzegania regulaminu i wystąpienia w sprawach proceduralnych”.

Pierwszym, podstawowym wnioskiem formalnym przewidzianym przez art. 195 regulaminu PE jest wniosek w sprawie przestrzegania regulaminu. Zgod-

46 Zgodnie $\mathrm{z}$ informacją zawartą w glosariuszu na stronie internetowej Izby Gmin, A point of order is an appeal to the Chair or Speaker for clarification or for a ruling on a matter of procedure in the House of Commons. The MP must explain their reasons for believing the rules of the House have been broken and the Speaker decides whether it is a valid point of order or not, https://www.parliament.uk/site-information/glossary/ point-of-order/. Https://guidetoprocedure.parliament.uk/articles/f1Oqrfli/points-of-order.

Członek Izby Gmin zgłasza wniosek, wypowiadając formułę: That the House sit in private. Szerzej na temat tych wniosków zob. MPs' Guide to Procedure, https://guidetoprocedure.parliament.uk/articles/vh8F2aPq/motion-to-sit-in-private. That the question be now put. Szerzej na temat tych wniosków zob. MPs' Guide to Procedure, https://guidetoprocedure.parliament.uk/articles/SaPSvNmb/how-to-move-the-closure. Https://www.europarl.europa.eu/doceo/document/lastrules/TOC_PL.html?redirect. 
nie $\mathrm{z}$ dyspozycją art. 195 ust. 1 poseł może zabrać głos w celu zwrócenia uwagi przewodniczącego na nieprzestrzeganie regulaminu PE. Na początku swojego wystąpienia poseł wskazuje artykuł, do którego się odnosi. Wnioski tego rodzaju mają pierwszeństwo przed innymi wnioskami o udzielenie głosu lub pozostałymi wnioskami proceduralnymi. Czas wystąpienia jest w tym wypadku ograniczony do jednej minuty (art. 195 ust. 3). W przypadku wniosku w sprawie przestrzegania regulaminu przewodniczący niezwłocznie podejmuje decyzję w tej sprawie zgodnie z postanowieniami regulaminu i ogłasza ją bezpośrednio po zgłoszeniu wniosku. Przewodniczący może oświadczyć, że jego decyzja zostanie ogłoszona później, jednakże nie może jej ogłosić w terminie przekraczającym 24 godziny po zgłoszeniu wniosku w sprawie przestrzegania regulaminu. Przełożenie terminu podjęcia decyzji nie pociąga za sobą odroczenia debaty.

Obok podstawowego wniosku, jakim jest wniosek o przestrzeganie regulaminu, w PE istnieje też pięć szczegółowych postaci wniosków o charakterze wniosków formalnych. Pierwszym takim rodzajem jest tzw. wniosek proceduralny. Odpowiada on w największym stopniu polskiemu wnioskowi formalnemu. Artykuł 196 regulaminu PE wyodrębnia pięć rodzajów wniosków proceduralnych. Pierwszym jest wniosek o stwierdzenie niedopuszczalności (szczegółowo uregulowany w art. 197). Drugim jest wniosek o odesłanie do komisji (art. 198). Trzecim jest wniosek o zamknięcie debaty (art. 199). Czwartym jest wniosek o odroczenie debaty lub głosowania (art. 200). Ostatnim, piątym rodzajem wniosku proceduralnego jest wniosek o zawieszenie lub przerwanie posiedzenia (art. 201). Cechą wspólną wszystkich wniosków proceduralnych jest to, że w celu ich zgłoszenia posłom PE udziela się głosu poza kolejnością. W sprawie tych wniosków głos zabierać mogą, poza wnioskodawcą, jedynie jeden mówca będący przeciw, jak również przewodniczący lub sprawozdawca właściwej komisji, która zajmowała się sprawą objętą wnioskiem. Zgodnie z przepisem art. 196 ust. 2 czas wystąpienia w przypadku każdego wniosku proceduralnego jest ograniczony do jednej minuty.

Artykuł 197 regulaminu PE określa osobno wniosek o stwierdzenie niedopuszczalności. W momencie otwarcia debaty nad danym punktem porządku dziennego grupa polityczna lub posłowie w liczbie stanowiącej co najmniej niski próg ${ }^{51}$ mogą wystąpić $\mathrm{z}$ wnioskiem o stwierdzenie niedopuszczalności tego punktu porządku dziennego. Głosowanie nad tym wnioskiem przeprowadza się niezwłocznie. Należy jednak dodać, że w przeciwieństwie do polskiego wniosku formalnego, zamiar złożenia wniosku o stwierdzenie niedopuszczalności powinien być zgłoszony co najmniej 24 godziny wcześniej przewodniczącemu, który informuje o nim niezwłocznie Parlament. Jeśli wniosek został przyjęty, posłowie przechodzą od razu do następnego punktu porządku dziennego. Podobnie jest

51 Co oznacza $1 \frac{1}{20}$ całkowitej liczby posłów do PE lub grupę polityczną - zob. art. 179 ust. 1 regulaminu PE. 
z kolejnym rodzajem wniosku proceduralnego, tj. wnioskiem o odesłanie do komisji. Co do zasady także i w tym wypadku (art. 198) zamiar złożenia wniosku o odesłanie do komisji jest zgłaszany co najmniej 24 godziny wcześniej przewodniczącemu, który niezwłocznie informuje o nim Parlament. O odesłanie sprawy do komisji może wnioskować grupa polityczna lub posłowie w liczbie stanowiącej co najmniej niski próg podczas ustalania porządku dziennego lub przed otwarciem debaty. Niemniej w tym wypadku regulamin dopuszcza możliwość wnioskowania o odesłanie do komisji także i nagle, tj. przed głosowaniem lub w jego trakcie. Wniosek taki jest niezwłocznie poddawany pod głosowanie. Zarazem wniosek o odesłanie do komisji może być zgłoszony tylko raz na każdym z etapów procedury (art. 198 ust. 3). Odesłanie do komisji zawiesza rozpatrywanie danego punktu. Parlament może wyznaczyć komisji termin, w jakim powinna ona przedstawić swoje wnioski. Artykuł 199 regulaminu PE określa również kategorię wniosku o zamknięcie debaty. W tym wypadku przewodniczący, na wniosek grupy politycznej lub posłów w liczbie stanowiącej co najmniej niski próg, może zaproponować zamknięcie debaty, zanim zabiorą głos wszyscy mówcy figurujący na liście. Głosowanie nad propozycją lub wnioskiem przeprowadza się niezwłocznie. Jeżeli propozycja lub wniosek zostaną przyjęte, głos może zabrać tylko jeden poseł z każdej grupy, która nie wzięła jeszcze udziału w debacie. Po tych wystąpieniach następuje zamknięcie debaty i Parlament przystępuje do głosowania nad omawianym punktem, chyba że wcześniej został ustalony inny termin głosowania. Jeśli wniosek odrzucono, może być on powtórnie przedstawiony w czasie tej samej debaty jedynie przez przewodniczącego. Jeszcze inną postacią wniosku proceduralnego jest wniosek z art. 200, tj. wniosek o odroczenie debaty lub głosowania. Wniosek taki może zgłosić grupa polityczna lub posłowie w liczbie stanowiącej co najmniej niski próg w chwili trwania debaty nad danym punktem porządku dziennego. Jednocześnie zamiar złożenia wniosku o odroczenie debaty powinien być zgłoszony co najmniej 24 godziny wcześniej przewodniczącemu, który informuje o nim niezwłocznie Parlament. Głosowanie nad takim wnioskiem przeprowadza się niezwłocznie. Jeżeli wniosek został przyjęty, Parlament przechodzi do następnego punktu porządku dziennego. Odroczona debata jest podejmowana w wyznaczonym terminie. Jeżeli wniosek odrzucono, nie może być on przedstawiony ponownie w trakcie tej samej sesji miesięcznej.

Ostatnim wnioskiem proceduralnym jest wniosek o zawieszenie lub zamknięcie posiedzenia. Posiedzenie może zostać zawieszone lub zamknięte w trakcie debaty lub głosowania, jeżeli decyzję taką podejmie Parlament na podstawie propozycji przewodniczącego lub na wniosek posłów lub grupy politycznej (grup politycznych) w liczbie stanowiącej co najmniej wysoki próg ${ }^{52}$. Głosowanie

52 Wysoki próg oznacza $1 / 5$ całkowitej liczby posłów do PE, tworzoną przez jedną lub więcej grup politycznych bądź przez poszczególnych posłów lub przez kombinację obu tych opcji. 
nad tą propozycją lub wnioskiem przeprowadza się niezwłocznie. Jednocześnie w przypadku złożenia wniosku o zawieszenie lub zamknięcie posiedzenia procedurę głosowania nad tym wnioskiem wszczyna się bez zbędnej zwłoki. Stosuje się zwyczajowe środki ogłaszania głosowań plenarnych i zgodnie z obecną praktyką zapewnia się posłom dość czasu na dotarcie do sali obrad plenarnych.

\section{Bibliografia}

Chybalski P., Wniosek formalny [w:] Wielki słownik parlamentarny, red. J. Szymanek, Warszawa 2018.

Davis Ch.M., Commonly Used Motions and Requests in the House of Representatives. Report prepared for Members and Committees of Congress, Congressional Research Service, 16 września 2015.

Komentarz do Regulaminu Sejmu Rzeczypospolitej Polskiej, red. A. Szmyt, Warszawa 2018. Sarnecki P., Art. 184 [w:] Komentarz do Regulaminu Sejmu Rzeczypospolitej Polskiej, red. A. Szmyt, Warszawa 2018. 